\title{
Makalah Penjas
}

\section{Mengenai Penyakit Menular}

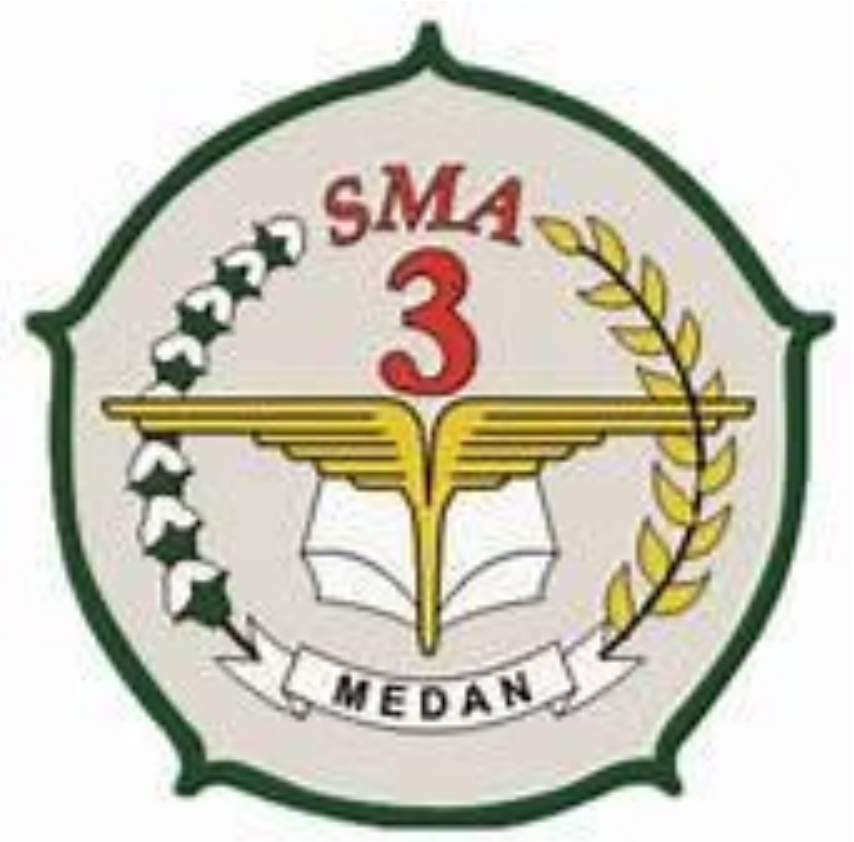

Disusun Oleh: CINDY FAZILA-X MIA 3 


\section{Kata Pengantar}

Puji syukur kehadirat Allah SWT yang telah memberikan

rahmat dan hidayah-Nya sehingga saya dapat menyelesaikan tugas makalah yang bertema "Penyakit Menular" ini tepat pada waktunya.

Adapun tujuan dari penulisan dari makalah ini adalah untuk memenuhi tugas pada bidang Pendidikan Jasmani Olahraga dan Kesehatan [PJOK] Selain itu, makalah ini juga bertujuan untuk menambah wawasan tentang penyakit menular bagi para pembaca dan juga bagi penulis. 


\section{DAFTAR ISI}

Bab 1 : Pendahuluan
A. Latar Belakang
B. Identifikasi masalah
C. Batasan masalah
D. Rumusan masalah
E. Tujuan masalah

Bab 2 : Pembahasan Kajian Teori
A. Pengertian Teori
B. Hakikat Teori

KESIMPULAN

DAFTAR PUSTAKA 


\section{BAB 1}

\section{PENDAHULUAN}

\section{A. Latar Belakang}

Setiap manusia pernah mengalami sakit. Penyakit yang diderita oleh setiap makhluk berbeda satu dan yang lainnya. Sakit merupakan suatu keadaan dimana tubuh tidak berada pada kondisi normal yang disebabkan oleh beberapa faktor dari dalam maupun luar tubuh. Berdasarkan karakteristiknya penyakit dapat digolongkan menjadi 2 yaitu penyakit menular dan penyakit tidak menular. Penyakit menular mendapatkan perhatian yang lebih dari pemerintah dibanding dengan penyakit tidak menular. Penyakit menular adalah penyakit yang disebabkan oleh bakteri, virus, atau parasit yang dapat ditularkan melalui media tertentu. Penyakit menular sering juga disebut penyakit infeksi karena penyakit ini diderita melalui infeksi virus, bakteri, atau parasit yang ditularkan melalui berbagai macam media seperti udara, jarum suntik, transfusi darah, tempat makan atau minum, dan lain sebagainya (Vatimatunnimah, 2013). Penyakit menular merupakan hasil perpaduan berbagai faktor yang saling mempengaruhi.Penyakit menular maupun gangguan kesehatan pada manusia, tidak terlepas dari peran faktor lingkungan. Hubungan interaktif antara manusia serta perilakunya dengan komponen lingkungan yang memiliki potensi bahaya penyakit, juga dikenal sebagai proses kejadian penyakit. Sedangkan proses kejadian penyakit satu dengan yang lain masingmasing mempunyai karakteristik tersendiri. Dalam hal ini faktor lingkungan memegang peranan sangat penting.Interaksi manusia dengan lingkungan telah menyebabkan kontak antara kuman,virus, dan bakteri dengan manusia. Sering terjadi mikroorganisme yang tinggal di tubuh host kemudian berpindah ke manusia karena manusia tidak mampu menjaga kebersihan lingkungan. Hal ini tercermin dari tingginya kejadian penyakit menular berbasis lingkungan yang masih merupakan masalah kesehatan terbesar masyarakat Indonesia. Salah satu penyakit menular yang disebabkan oleh virus dan dapat menular ke manusia ialah Virus Corona.

\section{B. Identifikasi Masalah}

Penyakit menular dapat menyebar melalu media langsung, udara, air, benda dan vector penyakit. Salah satu penyakit menular yang tengah ramai diperbincangkan di dunia ialah COVID-19. COVID-19 merupakan penyakit yang disebabkan oleh virus corona jenis baru yang dapat ditularkan secara tidak langsung melalui benda yang telah disentuh oleh orang 
yang membawa virus tersebut atau carrier. Virus corona merupakan virus yang telah ada sejak tahun 1930-an dan merupakan virus yang menyebabkan penyakit SARS dan MERS, namun virus ini kembali ramai diperbincangkan mulai dari awal tahun 2020 karena muncul penyakit baru yaitu COVID-19. Virus corona yang sedang ramai saat ini merupakan virus corona jenis baru yang menyebabkan banyak orang terinfeksi dan memakan korban jiwa. Virus corona dipercaya merupakan virus yang awalnya bermula dari hewan dan hanya menularkan ke hewan lainnya, tetapi seiring perkembangan zaman, virus ini dapat menyebar dari manusia ke manusia, Virus corona atau penyakit COVID-19 ini dipercaya berasal dari Pasar seafood Wuhan, Provinsi Hubei, China. Namun, ada beberapa orang yang percaya bahwa virus ini berasal dari laboratorium di Tiongkok. Virus ini telah dikonfirmasi terinfeksi oleh manusia sebanyak kurang lebih sekitar 3,6 juta orang dan telah memakan korban jiwa sekitar 250 ribu orang di dunia. Sementara di Indonesia, Ada sekitar 12 ribu kasus COVID-19 yang telah ditemukan dan ada 872 orang yang telah meninggal dunia. Walaupun ada banyak orang yang meninggal dunia tetapi ada juga yang telah sembu daei COVID-19. Di dunia ada sekita 12 juta orang yang dinyatakan telah sembuh dari COVID-19, sementara di Indonesia ada sekitar 1.200-an orang yang dinyatakan telah sembuh dari penyakit tersebut.

\section{Batasan Masalah}

Untuk menghindari pembahasan yang terlalu luas dan kurang efektif, maka makalah ini dibuat batasan masalah yaitu :

1) Penyakit menular yang akan dibahas dalam makalah ini ialah COVID-19, yang sedang terjadi di dunia.

2) Pada sistem input adalah gejala yang diderita pasien, tidak melihat faktor lain seperti pola hidup, riwayat keturunan, dan sebagainya

3) Penyakit ini dapat diderita oleh semua orang, tidak dilihat berdasarkan umur.

4) Resiko kematian yang paling tinggi adalah pasien lansia.

D. Rumusan Masalah

1) Apa itu penyakit menular?

2) Apa saja jenis-jenis penyakit menular yang dapat menular ke masyarakat?

3) Apa itu virus corona? 
4) Apa itu COVID-19?

5) Bagaimana proses munculnya COVID-19 di dunia?

6) Bagaimana proses terjadinya COVID-19 di Indonesia?

E. Tujuan Masalah

1) Untuk mengetahui apa itu penyakit menular

2) Untuk mengetahui jenis-jenis penyakit menular

3) Untuk mengetahui apa yang dimaksud dengan virus corona

4) Untuk mengetahui apa itu COVID-19

5) Untuk mengetahui bagaimana proses munculnya COVID-19 di dunia

6) Untuk mengetahui bagaimana proses terjadinya COVID-19 di dunia 


\section{BAB II}

\section{PEMBAHASAN}

Kajian Teori

\section{A. Pengertian Teori}

Penyakit menular ialah penyakit yang dapat berpindah dari seseorang ke orang lain. Penyakit dapat ditularkan baik melalui kontak langsung dengan penderita, melalui binatang perantara, udara, makanan dan minuman, atau benda-benda yang sudah tercemar oleh bakteri, virus, cendawan, atau jamur.

Masalah dominannya penyakit menular dalam komposisi penyakit yang abadi di Indonesia tentu tidak menggembirakan. Berkembangnya penyakit menular di Indonesia merupakan akibat dari rendahnya tingkat pendidikan masyarakat, ditambah lagi dengan keadaan lingkungan yang kurang terawat menyebabkan munculnya berbagai wabah penyakit. Untuk mencegah dan mengatasi wabah penyakit itu, pemerintah membekali setiap petugas kesehatan dengan pengetahuan dan keterampilan untuk pence-gahan serta penanganan masalah wabah penyakit menular tersebut.

Cara-Cara Penularan Penyakit Menular

a. Melalui Kontak Jasmani (Personal Contact)

Kontak jasmani terdiri atas dua jenis, yaitu kontak langsung dan kontak tidaklangsung.

1) Kontah Langsung (Direct Contact)

Penyakit dapat menular kepada orang lain karena adanya kontak langsung antara anggota badan dengan anggota badan orang yang ditulari. Misalnya, penularan penyakit kelamin dan penyakit kulit.

2) Kontak Tak Langsung (Indirect Contact)

Penyakit dapat menular kepada orang lain melalui perantaraan benda-benda yang telah terkontaminasi (tercemar) oleh penderita, misalnya melalui handuk, pakaian, dansaputangan. 


\section{b. Melalui Makanan dan Minuman (Food Borne Infection)}

Penyakit dapat menular melalui peran $\neg$ taraan makanan dan minuman yang telah terkontaminasi. Penyakit yang menular dengan cara ini terutama penyakit-penyakit yang berhubungan dengan saluran percerna-kan makanan, seperti kolera, tifus, poliomye $\neg$ litis, hepatitis, dan penyakit-penyakit yang disebabkan oleh cacing. Di negara miskin masih banyak orang menggunakan air yang tidak memenuhi syarat kesehatan untuk keperluan rumah tangga sehingga penyakit-penyakit tersebut seringkali ditularkan melalui air. Oleh karena itu, penyakit tersebut dinamakan juga water borne diseases.

c. Melalui Serangga (Insect Borne Infection)

Penyakit yang dapat menular dengan perantara serangga, antara lain sebagaiberikut.

1. Malaria, yang disebabkan oleh Plasmodium dan ditularkan oleh nyamuk Anopheles.

2. Demam berdarah, yang disebabkan oleh salah satu virus dari selotipe genusflavivirus dan ditularkan oleh nyamuk Aedes aegypti.

3. Demam kuning, yang disebabkan oleh arbovirus dan ditularkan oleh nyamuk Aedes aegypti.

4. Filariasis atau penyakit kaki gajah, yang disebabkan oleh cacing Filaria bancroftiatau Filaria malayi, ditularkan oleh nyamuk Culex fatigans.

5. Penyakit saluran pencernaan makanan dapat ditularkan oleh lalat yang dipindah-kan dari feses (kotoran) penderita ke makanan atau alat-alat makan.

\section{d. Melalui Udara (Air Borne Infection)}

Penyakit yang ditularkan dengan cara ini terutama pada penyakit saluran pernapasan, di antaranya sebagai berikut.

1. Melalui udara yang mengandung bibit penyakitnya, misalnya penularan penyakit TB.

2. Melalui ludah ketika batuk atau ber-cakap-cakap, misalnya penularan penyakit dipteri dan pertusis.

Jenis-Jenis Penyakit Menular yang Bersumber Lingkungan Tidak Sehat 
Salah satu kebutuhan penting akan kesehatan lingkungan adalah masalah air bersih, persampahan dan sanitasi, yaitu kebutuhan akan air bersih, pengelolaan sampah yang setiap hari diproduksi oleh masyarakat serta pembuangan air limbah yang langsung dialirkan pada saluran/sungai. Hal tersebut menyebabkan pandangkalan saluran/sungai, tersumbatnya saluran/sungai karena sampah. Pada saat musim penghujan selalu terjadi banjir dan menimbulkan penyakit.

Beberapa penyakit yang ditimbulkan oleh sanitasi yang kurang baik serta pembuangan sampah dan air limbah yang kurang baik diantaranya adalah:

\section{a. Penyakit Tifus}

1. Penyebab: bakteri Salmonella typhi.

2. Masa inkubasi: $10-14$ hari.

3. Cara penularan: melalui makanan dan minuman yang mengandung Salmonella twhi.

\section{b. Penyakit Kolera}

1. Penyebab: Vibrio Cholerae untuk kolera asiatica dan Vibrio Cholerae Eltor untuk kolera eltor.

2. Masa inkubasi: beberapa jam sampai 5 hari.

3. Cara penularannya: melalui makanan dan minuman yang terkontaminasi (tercemar) oleh bibit penyakit kolera.

c. Penyakit Tuberculosis (TB)

1. Penyebab: bakteri Mycobacterium Tuberculosa.

2. Masa inkubasi: antara 4-6 minggu.

3. Cara penularannya: 
-. melalui pernapasan, bakteri masuk ke dalam paru-paru bersama udara,

-. melalui susu sapi yang diminum tanpa dipasteurisasi terlebih dahulu.

d. Penyakit Hepatitis

Hepatitis ialah peradangan hati yang menahun karena suatu infeksi atau keracun-an.

1. Penyebab: penyebab penyakit hepatitis ialah virus.

2. Masa inkubasi: selama 2-6 minggu

3. Cara penularan:

-. Pada ibu hamil bila terserang virus hepatitis B dapat menularkan pada bayinya yang ada di dalam kandung-an atau sewaktu menyusui. Bentuk penularan seperti inilah yang sering dijumpai pada penyakit hepatitis B.

-. Penularan hepatitis C dan Delta melalui tranfusi darah.

-. Hepatitis E penularannya melalui mulut.

\section{B. Hakikat Teori}

Salah satu contoh penyakit menular secara tidak langsung ialah COVID-19 yang dapat menularkan virus corona melalui benda yang telah disentuh oleh orang yang terinfeksi virus tersebut (carrier).

\section{Virus Corona}

Virus corona adalah adalah keluarga besar virus yang menyebabkan penyakit mulai dari gejala ringan sampai berat. Ada setidaknya dua jenis virus corona yang diketahui menyebabkan penyakit yang dapat menimbulkan gejala berat seperti Middle East Respiratory Syndrome (MERS) dan Severe Acute Respiratory Syndrome (SARS). Virus corona adalah 
zoonosis (ditularkan antara hewan dan manusia). Penelitian menyebutkan bahwa SARS ditransmisikan dari kucing luwak (civet cats) ke manusia dan MERS dari unta ke manusia. Beberapa coronavirus yang dikenal beredar pada hewan namun belum terbukti menginfeksi manusia.

\section{COVID-19}

Coronavirus Disease (COVID-19) adalah virus jenis baru yang belum pernah diidentifikasi sebelumnya pada manusia. COVID-19 merupakan virus corona yang pertama kali terbukti dapat menularkan dari manusia ke manusia lainnya.

COVID-19 adalah penyakit menular yang disebabkan oleh jenis coronavirus yang baru ditemukan. Ini merupakan virus baru dan penyakit yang sebelumnya tidak dikenal sebelum terjadi wabah di Wuhan, Tiongkok, bulan Desember 2019. Gejala-gejala COVID-19 yang paling umum adalah demam, rasa lelah, dan batuk kering. Beberapa pasien mungkin mengalami rasa nyeri dan sakit, hidung tersumbat, pilek, sakit tenggorokan atau diare, Gejala-gejala yang dialami biasanya bersifat ringan dan muncul secara bertahap. Beberapa orang yang terinfeksi tidak menunjukkan gejala apa pun dan tetap merasa sehat. Sebagian besar (sekitar 80\%) orang yang terinfeksi berhasil pulih tanpa perlu perawatan khusus. Sekitar 1 dari 6 orang yang terjangkit COVID-19 menderita sakit parah dan kesulitan bernapas. Orang-orang lanjut usia (lansia) dan orang-orang dengan kondisi medis yang sudah ada sebelumnya seperti tekanan darah tinggi, gangguan jantung atau diabetes, punya kemungkinan lebih besar mengalami sakit lebih serius. Mereka yang mengalami demam, batuk dan kesulitan bernapas sebaiknya mencari pertolongan medis.

Cara-cara untuk melindungi diri dari COVID-19, yaitu :

1) Secara teratur dan menyeluruh bersihkan tangan Anda dengan sabun dan air atau cairan berbasis alkohol. Mencuci tangan dengan sabun dan air atau menggunakan cairan berbasis alkohol membunuh virus yang mungkin ada di tangan Anda.

2) Pertahankan jarak fisik atau physical distancing setidaknya 1 meter (3 kaki) antara Anda dan siapa saja yang batuk atau bersin. Ketika seseorang batuk atau bersin, mereka menyemprotkan tetesan cairan kecil dari hidung atau mulut mereka yang mungkin mengandung virus. Jika Anda terlalu dekat, Anda bisa menghirup tetesan air, termasuk virus COVID-19 jika orang tersebut menderita batuk. 
3) Hindari menyentuh mata, hidung dan mulut. Tangan menyentuh banyak permukaan dan virus dapat menempel. Setelah terkontaminasi, tangan dapat memindahkan virus ke mata, hidung, atau mulut Anda. Dari sana, virus bisa masuk ke tubuh Anda dan bisa membuat Anda sakit.

4) Pastikan Anda, dan orang-orang di sekitar Anda, menjaga kebersihan pernapasan. Ini berarti menutupi mulut dan hidung Anda dengan siku atau anggota badan yang tertekuk saat Anda batuk atau bersin. Kemudian segera buang tisu bekas yang digunakan untuk menutupi bersih atau batuk. Tetesan yang keluar saat Anda bersin atau batuk menyebarkan virus. Dengan mengikuti saran ini, Anda melindungi orang-orang di sekitar Anda dari virus.

5) Tetap di rumah jika Anda merasa tidak sehat. Jika Anda mengalami demam, batuk dan kesulitan bernapas, cari bantuan medis dan hubungi mereka terlebih dahulu. Ikuti arahan otoritas kesehatan setempat Anda. Otoritas nasional dan lokal akan memiliki informasi terbaru tentang situasi di daerah Anda. Menelepon terlebih dahulu akan memungkinkan penyedia layanan kesehatan mengarahkan Anda ke fasilitas kesehatan yang tepat. Ini juga akan melindungi Anda dan membantu mencegah penyebaran virus dan infeksi lainnya.

Munculnya COVID-19 di dunia

Pada awal bulan Desember 2019 sejumlah pasien dengan penyakit tak dikenal, berdatangan ke rumah sakit pusat Wuhan, China. Mendiang Dr. Li Wenliang sempat menyampaikan kabar buruk itu di media sosial. Dia memberikan pesan yang mengejutkan di grup alumni sekolah kedokterannya melalui aplikasi pesan singkat yang populer di China, WeChat. Li menjelaskan, menurut sebuah tes yang telah dilihatnya, penyakit yang diderita mereka adalah virus corona, yang ternyata satu keluarga dengan virus sindrom pernapasan akut (SARS). Segera setelah dia mengunggah pesan itu, Li dituduh menyebarkan isu oleh polisi Wuhan. Dia adalah salah satu dari beberapa petugas medis yang menjadi sasaran polisi karena berusaha untuk mengungkap virus mematikan ini di pekan-pekan awal sebelum terjadinya wabah.

Pada waktu yang sama ketika Li mengirim pesan kepada teman-temannya, sebuah pemberitahuan darurat dikeluarkan oleh Komisi Kesehatan Kota Wuhan, yang berisikan 
pemberitahuan kepada institusi medis kota jika ada beberapa pasien dari Pasar Grosir Makanan Laut Huanan mengalami pneumonia yang tidak diketahui.

Menurut surat kabar pemerintah Beijing Youth Daily, dini hari tanggal 31 Desember, otoritas kesehatan Wuhan mengadakan pertemuan darurat untuk membahas wabah tersebut. Setelah itu, Li dipanggil oleh pejabat rumah sakitnya agar menjelaskan bagaimana dia bisa tahu tentang kasus-kasus itu.

Tanggal 3 Januari 2020, Li dipanggil ke kantor polisi setempat dan ditegur karena menyebarkan desas-desus yang sangat mengganggu ketertiban sosial atas pesan yang dia kirimkan dalam grup obrolan.Sejak awal, pihak berwenang China ingin mengendalikan informasi tentang wabah itu, membungkam suara apa pun yang berbeda dengan narasinya, terlepas dari apakah mereka mengatakan yang sebenarnya.

Li menyebarkan informasi soal virus corona yang ia periksa. Kemudian pihak kepolisian mengetahui informasi tersebut melalui aplikasi WeChat.Usai dipanggil pihak kepolisian China, Li harus menandatangani pernyataan untuk mengakui kesalahan dan berjanji untuk tidak melakukan tindakan melanggar hukum lebih lanjut.

Dia takut akan ditahan. "Keluarga saya akan khawatir tentang saya, jika saya kehilangan kebebasan saya selama beberapa hari," katanya kepada CNN melalui pesan teks di WeChat. Li terdengar batuk terlalu banyak dan napasnya tidak teratur untuk berbicara melalui telepon. Untungnya, Li diizinkan meninggalkan kantor polisi setelah satu jam berada di sana.Li sempat mengklarifikasi pernyataannya dalam pesan berikutnya yang menyatakan bahwa virus itu sebenarnya adalah tipe virus corona yang berbeda. Sangat disayangkan, tangkapan layar dari pesan pertama Li sudah menyebar di dunia maya.

Proses penyebaran COVID-19 di Indonesia

Pada 14 Februari 2020, WNI berusia 31 tahun diduga terjangkit virus corona saat berada di sebuah restoran di Jakarta. Dia tertular dari warga Jepang yang saat itu juga sedang di tempat yang sama. WNI dan warga negara Jepang yang tinggal di Malaysia itu diketahui melakukan kontak cukup dekat atau close contact.Kontak yang dimaksud dekat adalah jarak yang memungkinkan virus itu menular. Pasien 1 itu kemudian melakukan kontak dengan Pasien 2, yang merupakan ibunya. Sang ibu tertular virus corona saat sedang merawat anaknya yang 
sakit. Menteri Kesehatan Terawan Agus Putranto menyebutkan bahwa dua orang itu tinggal di Depok, Jawa Barat.

Dua hari kemudian, 16 Februari 2020, ibu dan anak itu melakukan pemeriksaan di rumah sakit di Depok. Saat itu, keduanya hanya diminta untuk rawat jalan. Pada 26 Februari 2020, kondisi keduanya belum membaik dan mereka meminta untuk rawat inap karena merasa batuknya tidak kunjung reda.Kemudian, pada 28 Februari 2020, terdapat informasi ke Tanah Air bahwa warga Jepang itu positif Covid-19 saat kembali ke Malaysia. Pemerintah kemudian menelusuri aktivitas warga Jepang itu, termasuk siapa saja yang dia temui. Hingga kemudian, hal ini membuat ditemukan keterkaitannya dengan Pasien 1.

Setelah penemuan Kasus 1 dan Kasus 2, pemerintah terus melakukan tracing dengan menelusuri aktivitas mereka. Hingga kemudian, ada dugaan virus corona itu tersebar di lokasi yang sama saat Kasus 1 melakukan kontak dekat dengan warga Jepang, di sebuah restoran di Jakarta Selatan. Penelusuran dilakukan dengan metode klaster, yaitu mencari orang-orang yang berada di lokasi yang sama, yaitu di restoran itu pada 14 Februari 2020.

Kasus 3 dan Kasus 4 itu diketahui berada di lokasi yang sama dengan Kasus 1, dan ada kemungkinan tertular Covid-19 di saat yang sama. Hal yang perlu dicatat adalah belum diketahui apakah penularan itu langsung dari warga Jepang atau dari pasien dalam kasus 1.Kemudian, pemerintah menelusuri dan mendapatkan 80 pengunjung dan orang yang berada di restoran itu pada 14 Februari 2020. Berikutnya, dilakukan screening hingga kemudian dikerucutkan menjadi 20 orang yang diminta untuk pendalaman. Sebanyak 20 orang itu dicari tahu seberapa dekat kontak yang dilakukan. Hasilnya, ada tujuh pasien yang dilakukan pemeriksaan lanjutan. Dari hasil pemeriksaan yang dilakukan di RSPI Sulianti Saroso, pemerintah kemudian memastikan ada tiga pasien lagi yang mengidap Covid-19, yaitu Kasus 3, 4, dan 5 yang merupakan pengunjung restoran tersebut. 


\section{KESIMPULAN}

Dari pembahasan diatas dapat kita simpulkan bahwa salah satu contoh penyakit menular secara tidak langsung yaitu COVID-19. COVID-19 merupakan penyakit jenis baru yang disebabkan oleh virus corona. COVID-19 ramai diperbincangkan diawal tahun 2020 karena penularannya begitu cepat dan memakan banyak korban jiwa. Walaupun belum ditemukan vaksin ataupun obat untuk COVID-19, tetapi banyak orang yang bisa sembuh dari penyakit ini.

\section{DAFTAR PUSTAKA}

https://cari-carimakalah.blogspot.com/2017/01/makalah-penyakit-menular.html?m=0 http://eprints.uny.ac.id/40665/1/BAB\%20I.pdf https://www.who.int/indonesia/news/novel-coronavirus/qa-for-public https://tirto.id/lakukan-5-hal-ini-untuk-mencegah-virus-corona-covid-19-eKpg https://www.suara.com/video/2020/04/03/135739/menilik-kembali-sejarah-kemunculancovid-19-yang-kini-jadi-pandemi https://www.merdeka.com/dunia/cerita-lengkap-asal-mula-munculnya-virus-corona-diwuhan.html 